\title{
Novel pathogenic XK mutations in McLeod syndrome and interaction between XK protein and chorein
}

Yuka Urata, MD, Masayuki Nakamura, MD, PhD, Natsuki Sasaki, MD, PhD, Nari Shiokawa, MD, PhD, Yoshiaki Nishida, MD, Kaoru Arai, MD, Hanae Hiwatashi, MS, Izumi Yokoyama, BS, Shinsuke Narumi, MD, Yasuo Terayama, MD, PhD, Takenobu Murakami, MD, PhD, Yoshikazu Ugawa, MD, PhD, Hiroki Sakamoto, MD, Satoshi Kaneko, MD, PhD, Yusuke Nakazawa, MD, Ryo Yamasaki, MD, PhD, Shoko Sadashima, MD, Toshiaki Sakai, MD, Hiroaki Arai, MD, and Akira Sano, MD, PhD

Neurol Genet 2019;5:e328. doi:10.1212/NXG.0000000000000328

\section{Abstract}

\section{Objective}

To identify XK pathologic mutations in 6 patients with suspected McLeod syndrome (MLS) and a possible interaction between the chorea-acanthocytosis (ChAc)- and MLS-responsible proteins: chorein and XK protein.

\section{Methods}

Erythrocyte membrane proteins from patients with suspected MLS and patients with ChAc, ChAc mutant carriers, and normal controls were analyzed by XK and chorein immunoblotting. We performed mutation analysis and XK immunoblotting to molecularly diagnose the patients with suspected MLS. Lysates of cultured cells were co-immunoprecipitated with anti-XK and anti-chorein antibodies.

\section{Results}

All suspected MLS cases were molecularly diagnosed with MLS, and novel mutations were identified. The average onset age was $46.8 \pm 8$ years, which was older than that of the patients with ChAc. The immunoblot analysis revealed remarkably reduced chorein immunoreactivity in all patients with MLS. The immunoprecipitation analysis indicated a direct or indirect chorein-XK interaction.

\section{Conclusions}

In this study, XK pathogenic mutations were identified in all 6 MLS cases, including novel mutations. Chorein immunoreactions were significantly reduced in MLS erythrocyte membranes. In addition, we demonstrated a possible interaction between the chorein and XK protein via molecular analysis. The reduction in chorein expression is similar to that between Kell antigens and XK protein, although the chorein-XK interaction is a possibly noncovalent binding unlike the covalent Kell-XK complex. Our results suggest that reduced chorein levels following lack of XK protein are possibly associated with molecular pathogenesis in MLS.

\author{
Correspondence \\ Dr. Nakamura \\ nakamu36@ \\ m.kufm.kagoshima-u.ac.jp
}




\section{Glossary}

MLS = McLeod syndrome; ChAc $=$ chorea-acanthocytosis; NA = neuroacanthocytosis.

Neuroacanthocytosis (NA) syndromes are rare neurodegenerative disorders exhibiting neurologic abnormalities and erythrocyte acanthocytosis. The core NA syndromes are characterized by degeneration of the striatum and huntingtonism. They comprise 2 main diseases: chorea-acanthocytosis (ChAc) and McLeod syndrome (MLS). ChAc is caused by loss-of-function mutations in VPS13A, ${ }^{1,2}$ leading to an absent or markedly reduced level of the encoding protein, chorein., 3 MLS is caused by loss-of-function mutations in the $X K$, leading to absent XK protein. ${ }^{5}$ Although later onset and cardiomyopathy may occur predominantly in MLS, ${ }^{6}$ the 2 diseases share almost their entire symptomology in the CNS and erythrocyte membrane. Although molecular interactions are assumed to exist between these diseases, no studies have as yet established a direct association.

\section{Methods}

\section{Human samples and mutation analysis}

All 6 patients with suspected MLS were Japanese males with clinically suspected NA (table). Six healthy male controls and 6 male patients with ChAc were matched to suspected MLS cases by age. A further 6 heterozygous ChAc mutant carriers were used for the analyses. Lymphoblastoid cell lines from MLS_ $1^{7}$ and a healthy control were established by SRL (Tokyo, Japan).

Coding and flanking regions of $X K$ (NC_000023.10) and VPS13A (NC_000009.11) were analyzed by Sanger sequencing on an ABI PRISM 3100 Avant Genetic Analyzer (Thermo Fisher Scientific, Waltham, MA). ${ }^{3}$ In the case of MLS_6, we performed a whole-genome sequence, long-range PCR covering the deletion region, and Sanger sequencing.

\section{Immunoprecipitation and immunoblot analysis}

Co-immunoprecipitation (co-IP) and reverse co-IP assays were performed using Dynabeads Protein G (Thermo Fisher Scientific). K562 and HEK293 cells that stably overexpressed chorein ${ }^{8}$ were lysed with Mammalian Protein Extraction Reagent (Thermo Fisher Scientific). K562 cells that were subcultured at $1 \times 10^{6}$ cells $/ \mathrm{mL}$ and incubated for 24 hours were used. The cell lysates (input) were used for the Dynabeadsantibody complex and Dynabeads-IgG complex. The cell lysate was diluted 5 times with $1 \times$ Tris-buffered saline because delicate surfactant conditions were required to maintain the IP interaction. The cell lysate and each bead were incubated for 2 hours at room temperature.

Protein samples were analyzed by immunoblotting using rabbit anti-chorein (HPA021662; Atlas Antibodies, Bromma,
Sweden) and rabbit anti-XK protein (HPA019036; Atlas Antibodies) primary antibodies, which show no crossreactivity with spectrin. Donkey anti-rabbit IgG, HRPlinked whole $\mathrm{Ab}$ (GE Health care, Little Chalfont, England) and VeriBlot for IP Detection Reagent (HRP) (ab131366; Abcam, Cambridge, UK) were used as secondary antibodies. Proteins were visualized using ECL Prime Western Blotting Detection Reagent (GE Health care), and images were recorded with a digital analyzer (FUSION-SOLO.7S.WL; Vilber Lourmat, Marne-la-Vallée, France).

\section{Standard protocol approvals, registrations, and patient consents}

Genomic DNAs and/or proteins from peripheral blood samples were taken from all participants who provided written informed consent. The research protocol and consent form were approved by the Institutional Review Boards of Kagoshima University.

\section{Data availability statement}

The data sets generated during and/or analyzed during the current study are available from the corresponding author on reasonable request.

\section{Results}

\section{Molecular diagnosis and clinical features of MLS cases}

For all suspected MLS cases, XK protein immunoreactivity was lacking in the immunoblot analysis of the erythrocyte membrane (figure 1A). Clinical symptoms and pathologic XK mutations are presented in the table In MLS_6, comprehensive mutation analysis revealed a mutation, which was a combination of a gross deletion and an insertion (figure 1, B-D).

\section{Chorein immunoreactivity reductions in all MLS cases}

We found a marked reduction in chorein immunoreactivity in all patients with MLS (figure 2A). The mean density level of patients with MLS was significantly lower $(p=0.00127, \mathrm{~d}=$ 2.6 ) at 0.55 , relative to controls (figure $2 \mathrm{D}$ ). The average reductions in the levels of chorein immunoreactivity in the erythrocyte membranes of MLS patients were equivalent to those found in heterozygous ChAc mutation carriers (figure 2, $\mathrm{C}$ and $\mathrm{D}$ ), although no pathogenic mutations were identified in VPS13A in any patients with MLS. On the other hand, the average density levels of the $\mathrm{XK}$ immunoreactions did not significantly differ between $\mathrm{ChAc}$ and ChAc mutant carriers and healthy controls in either the immunoblot or densitometric analyses (figure 2, B-E). Chorein immunoreactions of 
Table Profile of patients with MLS in this study

Clinical symptoms

\begin{tabular}{|c|c|c|c|c|c|c|c|c|c|c|c|c|c|c|}
\hline Case & $\begin{array}{l}\text { Age at } \\
\text { sampling }\end{array}$ & $\begin{array}{l}\text { Age } \\
\text { at } \\
\text { onset }\end{array}$ & $\begin{array}{l}\text { Initial } \\
\text { symptom }\end{array}$ & $\begin{array}{l}\text { Main } \\
\text { psychiatric } \\
\text { symptom }\end{array}$ & Acanthocytes & Chorea & $\begin{array}{l}\text { EEG } \\
\text { abnormality }\end{array}$ & $\begin{array}{l}\text { CK } \\
\text { (IU/L) }\end{array}$ & DTRs & Cardiomyopathy & $\begin{array}{l}\text { Atrophy of the } \\
\text { corpus striatum } \\
\text { on MRI }\end{array}$ & Exon & DNA change & $\begin{array}{l}\text { Protein } \\
\text { change }\end{array}$ \\
\hline MLS_1 & 64 & 47 & $\begin{array}{l}\text { Muscle } \\
\text { weakness }\end{array}$ & Insomnia & + & + & $\begin{array}{l}\text { Intermittent } \\
\text { theta wave }\end{array}$ & 5465 & Absent & - & + & $\begin{array}{l}\text { Exon } \\
3\end{array}$ & $\begin{array}{l}\text { c.del669- } \\
\text { 673TGTAGinsGGTCCTCTTTACC }\end{array}$ & p.V225Lfs*12 \\
\hline MLS_2 & 61 & 53 & $\begin{array}{l}\text { Involuntary } \\
\text { movement }\end{array}$ & $?$ & $?$ & + & $?$ & $?$ & ${ }^{a}$ Hyperreflexia & $?$ & + & $\begin{array}{l}\text { Exon } \\
3\end{array}$ & c.1013delT & p.F338Sfs*70 \\
\hline MLS_3 & 69 & 43 & $\begin{array}{l}\text { Muscle } \\
\text { weakness }\end{array}$ & $\begin{array}{l}\text { Persecutory } \\
\text { delusion }\end{array}$ & + & $?$ & $?$ & 920 & Absent & + & $?$ & $\begin{array}{l}\text { Exon } \\
2\end{array}$ & c. $451 \mathrm{dupC}$ & p.Q151Pfs*47 \\
\hline MLS_4 & 56 & 33 & $\begin{array}{l}\text { Involuntary } \\
\text { movement }\end{array}$ & Depression & + & + & $\begin{array}{l}\text { 3-4 Hz slow } \\
\text { wave }\end{array}$ & 821 & Normal & - & + & $\begin{array}{l}\text { Exon } \\
2\end{array}$ & c. $370 \mathrm{C}>\mathrm{T}$ & p.Q124* \\
\hline MLS_5 & 65 & 50 & $\begin{array}{l}\text { Involuntary } \\
\text { movement }\end{array}$ & $\begin{array}{l}\text { Cognitive } \\
\text { decline }\end{array}$ & + & + & $?$ & 2,422 & $?$ & $?$ & $?$ & $\begin{array}{l}\text { Exon } \\
2\end{array}$ & c.397C > T & p.R133* \\
\hline MLS_6 & 70 & 55 & $\begin{array}{l}\text { Involuntary } \\
\text { movement }\end{array}$ & Obsessiveness & + & + & $?$ & 1,052 & Absent & - & - & $\begin{array}{l}\text { Exon } \\
3\end{array}$ & Gross deletion & Unknown \\
\hline
\end{tabular}

Abbreviations: $C K=$ creatine kinase; DTR $=$ deep tendon reflex.

Novel mutations were identified in MLS_4 and MLS_6.

Age at onset: age when first signs or symptoms appeared (yr).
a When DTR tests were performed, MLS_2 was affected with bacterial meningitis. 
A

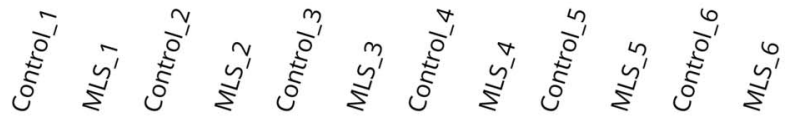

B

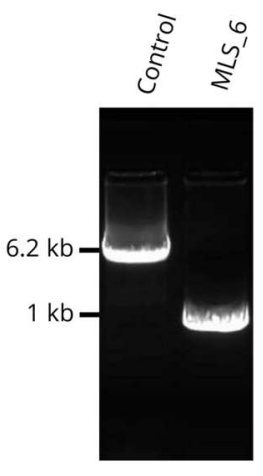

$X K-C Y B B$ Intergenic region
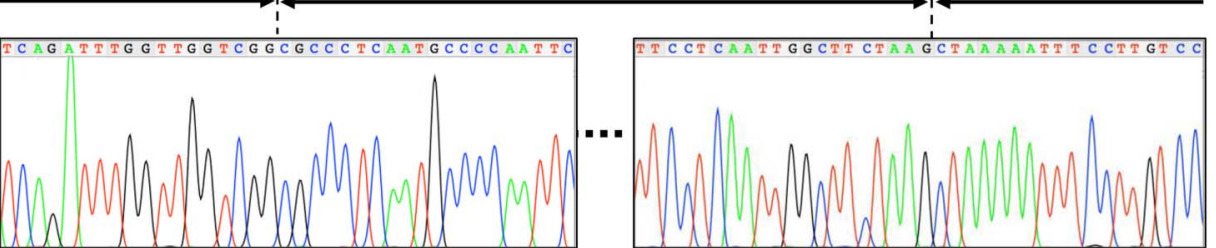

D

$X K$

CYBB
(A) The results of XK immunoblotting revealed a lack of XK immunoreactivity in all patients with MLS. Equal loading was shown by staining with MemCode reversible protein stain (Pierce), shown in the lower panel. (B) In the case of MLS_6, the XK gene mutation was predicted to be a gross deletion including exon 3 based on the results of gDNA amplification. To identify the breakpoints of this mutation, we performed a whole-genome analysis. Based on the results, we performed a long-range PCR covering the deletion region. The results of long-range PCR for MLS_6 showed a gross deletion mutation that was approximately 5500 bp in size. (C) Sanger sequencing results revealed a combination of a gross deletion, from intron 2 (c.509-636) to an XKCYBB intergenic region (c. $* 3667+$ 670 ), and an insertion of a complementary sequence of $380 \mathrm{bp}$ in intron 2. (D) The schematic shows the structure of the gross deletion region in MLS_6. the lymphoblastoid cell lysates from MLS 1 and the control were equivalent. In addition, there was no immunoreaction corresponding to the XK protein band in both control and MLS_1 lymphoblastoid cells (figure 2F).

\section{Chorein-XK protein interaction in cultured cells}

Cell lysates extracted from K562 cells were immunoprecipitated with anti-XK antibody. In the subsequent immunoblot analysis, positive chorein bands were detected in the $\mathrm{XK}$ immunoprecipitants (figure $2 \mathrm{G}$ ). Because the endogenous chorein level was low, XK protein immunoreactivity was not visually observed in chorein immunoprecipitants. Therefore, co-IP and reverse co-IP assays were conducted in a similar manner using the lysate extracted from chorein stably overexpressing HEK293 cells. Signals positive for chorein and $\mathrm{XK}$ protein were detected in the $\mathrm{XK}$ and chorein immunoprecipitants, respectively (figure $2 \mathrm{H}$ ).

\section{Discussion}

In the present study, we analyzed 6 cases with MLS and confirmed the molecular diagnosis, as well as identifying 2 additional novel pathogenic mutations (table). The profile of 6 cases of MLS in this study was similar to those reported previously. ${ }^{6}$ In our MLS cases, the average onset age was 46.8 \pm 8 years, which is approximately 13 years older than that of patients with $\mathrm{ChAc}^{3}$ The disease duration for MLS may be longer than 30 years, which is typically longer than for ChAc. ${ }^{6}$ 
A
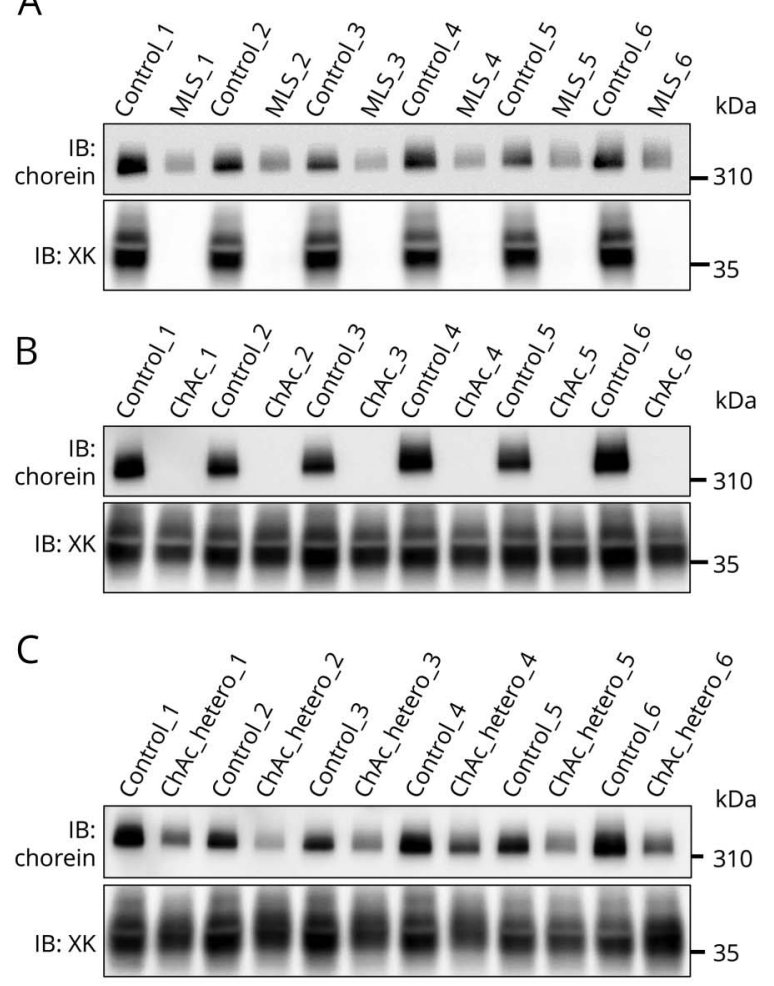
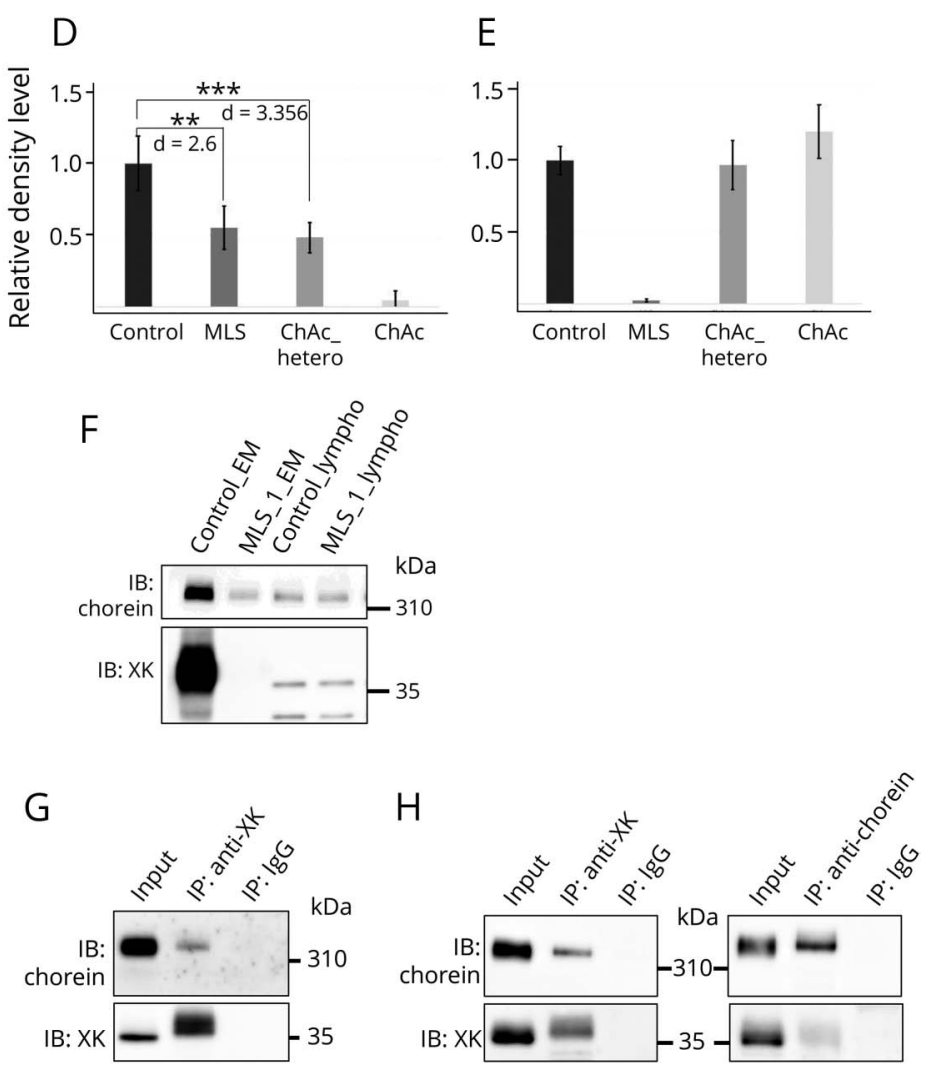

(A and C) Chorein immunoblotting results revealed reduced chorein immunoreactivity in the erythrocyte membranes of patients with MLS, which are equivalent to the heterozygous mutant carriers of ChAc (ChAc_hetero). (B and C) XK immunoblotting results revealed normal XK immunoreactivity in the erythrocyte membranes of ChAc and ChAc_hetero. (A-C) Each imaging was performed by underexposed condition for semiquantitative analysis. (D) The histograms show the chorein relative density ratio in patients with MLS and ChAc and ChAc_hetero. Each band density was normalized by protein density staining with MemCode reversible protein stain. Error bars represent the SD (each $n=6$ ); 2 -sample Student $t$ tests were performed accordingly on different sets of data. $* \star p<0.01 ; * \star * p<0.001$. d shows the effect size (Cohen's $d$ ). (E) The histograms show the XK protein relative density ratio in patients with MLS and ChAc and ChAc_hetero. Each band density was normalized by protein density staining with memcode reversible protein stain. (F) Chorein immunoblotting results revealed equivalent chorein immunoreactivity in the lymphoblastoid cells of MLS_1 and the control (MLS_1_lympho and Control_lympho, respectively). The XK immunoblotting of lymphoblastoid cells shown in the lower panel of figure 2 F reveals a lack of XK immunoreactivity. The Control_EM and MLS_EM lanes show the erythrocyte membrane for control and MLS, respectively. (G) Co-immunoprecipitation (IP) assay using K562 cells was performed with anti-XK antibody. Immunoblot analyses used anti-chorein (upper panel) and anti-XK antibodies (lower panel). (H) Co-IP and reverse co-IP assays using human embryonic kidney 293 (HEK293) cells stably overexpressing Myc-DDK-tagged chorein confirmed an interaction between XK protein and chorein. Immunoblot analyses used anti-XK protein and anti-chorein antibodies.

In the present study, semiquantitative chorein immunoblotting using erythrocyte membranes from all patients with MLS revealed significantly reduced chorein immunoreactions compared with age- and sex-matched healthy controls (figure 2A). Chorein immunoreactivities in heterozygous ChAc mutation carriers are also reduced to the same level as in patients with MLS (figure 2, C and D). These findings were demonstrated in at least triplicate independent experiments. Some ChAc mutation carriers exhibit partial symptoms of NA such as acanthocytosis. ${ }^{9}$ Taken together, the later onset and slower progression found for MLS compared with ChAc suggest that the chorein level reductions found in MLS may be directly associated with MLS molecular pathology. The erythrocyte membrane from 1 patient with MLS and lymphoblastoid cells from another patient with MLS showed normal chorein levels in previous study. ${ }^{4}$ In that study, chorein immunoblotting of heterozygous ChAc mutant carriers showed normal chorein levels, suggesting that the results of immunoblotting analysis might be unavailable for semiquantification.

In the present study, XK immunoblotting of lymphoblastoid cell lysate from healthy controls showed no XK protein band, suggesting no expression of XK protein in lymphoblastoid cells. This may account for the normal chorein immunoreaction found by chorein immunoblotting of lymphoblastoid cell lysate from MLS_1, although further investigation is required.

XK protein covalently interacts with Kell antigens, which are remarkably reduced in erythrocyte membranes of MLS patients. $^{6}$ In this study, based on the finding of reduced chorein in the erythrocyte membranes of patients with MLS, we hypothesized that the XK protein directly or indirectly interacts with chorein. In the present study, we performed IP assays, which revealed the possible interaction. In erythrocyte 
membranes, the absence of XK led to reduced chorein levels, although the absence of chorein was unrelated to XK levels. Computational analysis revealed a number of the corresponding impaired phosphorylation pathways in MLS and ChAc, suggesting a common molecular background bridging the generation of acanthocytes. ${ }^{10}$ In the present study, protein staining on blotting membranes revealed upshift in band 3 from both MLS and ChAc (data not shown), suggesting results of phosphorylation. Taken together, these results suggests that reduced chorein is associated with MLS phosphorylationrelated molecular pathology in the erythrocyte membranes. However, the direct mechanisms of reduced chorein in erythrocytes of MLS are unknown. In addition, our study did not include molecular investigations of the CNS. Further studies are needed to elucidate the molecular mechanism of NA.

\section{Acknowledgment}

The authors thank the patients with MLS, patients with ChAc, ChAc mutant carriers, and healthy controls for their participation, and Ms. Kyoko Meguro for her technical assistance.

\section{Study funding}

This study was supported by Grants-in Aid from the Research Committee of CNS Degenerative Diseases, Research on Policy Planning and Evaluation for Rare and Intractable Diseases, Health, Labour and Welfare Sciences Research Grants, and the Ministry of Health, Labour and Welfare, Japan, and in part by the Ministry of Education, Culture, Sports, Science and Technology KAKENHI (Grant No. 17H04250 to A.S. and No. 18 K07606 to M.N.).

\section{Disclosure}

Disclosures available: Neurology.org/NG.

\section{Publication history}

Received by Neurology: Genetics November 18, 2018. Accepted in final form March 7, 2019.

\section{Appendix Authors}

\begin{tabular}{|c|c|c|c|}
\hline Name & Location & Role & Contribution \\
\hline $\begin{array}{l}\text { Yuka Urata, } \\
\text { MD }\end{array}$ & $\begin{array}{l}\text { Kagoshima } \\
\text { University } \\
\text { Graduate School of } \\
\text { Medical and Dental } \\
\text { Sciences, } \\
\text { Kagoshima }\end{array}$ & Author & $\begin{array}{l}\text { Performed } \\
\text { laboratory work and } \\
\text { data analysis and } \\
\text { prepared the } \\
\text { manuscript }\end{array}$ \\
\hline $\begin{array}{l}\text { Masayuki } \\
\text { Nakamura, } \\
\text { MD, PhD }\end{array}$ & $\begin{array}{l}\text { Kagoshima } \\
\text { University } \\
\text { Graduate School of } \\
\text { Medical and Dental } \\
\text { Sciences, } \\
\text { Kagoshima }\end{array}$ & $\begin{array}{l}\text { Corresponding } \\
\text { author }\end{array}$ & $\begin{array}{l}\text { Supervised the } \\
\text { project, advised on } \\
\text { laboratory work and } \\
\text { data analysis, and } \\
\text { prepared the } \\
\text { manuscript }\end{array}$ \\
\hline $\begin{array}{l}\text { Natsuki } \\
\text { Sasaki, MD, } \\
\text { PhD }\end{array}$ & $\begin{array}{l}\text { Kagoshima } \\
\text { University } \\
\text { Graduate School of } \\
\text { Medical and Dental } \\
\text { Sciences, } \\
\text { Kagoshima }\end{array}$ & Author & $\begin{array}{l}\text { Advised on } \\
\text { laboratory work }\end{array}$ \\
\hline
\end{tabular}

Appendix (continued)

\begin{tabular}{|c|c|c|c|}
\hline Name & Location & Role & Contribution \\
\hline $\begin{array}{l}\text { Nari } \\
\text { Shiokawa, } \\
\text { MD, PhD }\end{array}$ & $\begin{array}{l}\text { Kagoshima } \\
\text { University } \\
\text { Graduate School of } \\
\text { Medical and Dental } \\
\text { Sciences, } \\
\text { Kagoshima }\end{array}$ & Author & $\begin{array}{l}\text { Advised on } \\
\text { laboratory work }\end{array}$ \\
\hline $\begin{array}{l}\text { Yoshiaki } \\
\text { Nishida, MD }\end{array}$ & $\begin{array}{l}\text { Kagoshima } \\
\text { University } \\
\text { Graduate School of } \\
\text { Medical and Dental } \\
\text { Sciences, } \\
\text { Kagoshima }\end{array}$ & Author & $\begin{array}{l}\text { Advised on data } \\
\text { analysis }\end{array}$ \\
\hline $\begin{array}{l}\text { Kaoru Arai, } \\
\text { MD }\end{array}$ & $\begin{array}{l}\text { Kagoshima } \\
\text { University } \\
\text { Graduate School of } \\
\text { Medical and Dental } \\
\text { Sciences, } \\
\text { Kagoshima }\end{array}$ & Author & $\begin{array}{l}\text { Advised on data } \\
\text { analysis }\end{array}$ \\
\hline $\begin{array}{l}\text { Hanae } \\
\text { Hiwatashi, } \\
\text { MS }\end{array}$ & $\begin{array}{l}\text { Kagoshima } \\
\text { University } \\
\text { Graduate School of } \\
\text { Medical and Dental } \\
\text { Sciences, } \\
\text { Kagoshima }\end{array}$ & Author & $\begin{array}{l}\text { Performed } \\
\text { laboratory work }\end{array}$ \\
\hline $\begin{array}{l}\text { Izumi } \\
\text { Yokoyama, } \\
\text { BS }\end{array}$ & $\begin{array}{l}\text { Kagoshima } \\
\text { University } \\
\text { Graduate School of } \\
\text { Medical and Dental } \\
\text { Sciences, } \\
\text { Kagoshima }\end{array}$ & Author & $\begin{array}{l}\text { Performed } \\
\text { laboratory work }\end{array}$ \\
\hline $\begin{array}{l}\text { Shinsuke } \\
\text { Narumi, MD }\end{array}$ & $\begin{array}{l}\text { Iwate Medical } \\
\text { University, Morioka }\end{array}$ & Author & $\begin{array}{l}\text { Collected clinical } \\
\text { data and blood } \\
\text { samples of study } \\
\text { patients }\end{array}$ \\
\hline $\begin{array}{l}\text { Yasuo } \\
\text { Terayama, } \\
\text { MD, PhD }\end{array}$ & $\begin{array}{l}\text { Iwate Medical } \\
\text { University, Morioka }\end{array}$ & Author & $\begin{array}{l}\text { Collected clinical } \\
\text { data and blood } \\
\text { samples of study } \\
\text { patients }\end{array}$ \\
\hline $\begin{array}{l}\text { Takenobu } \\
\text { Murakami, } \\
\text { MD, PhD }\end{array}$ & $\begin{array}{l}\text { Fukushima Medical } \\
\text { University, } \\
\text { Fukushima }\end{array}$ & Author & $\begin{array}{l}\text { Collected clinical } \\
\text { data and blood } \\
\text { samples of study } \\
\text { patients }\end{array}$ \\
\hline $\begin{array}{l}\text { Yoshikazu } \\
\text { Ugawa, MD, } \\
\text { PhD }\end{array}$ & $\begin{array}{l}\text { Fukushima Medical } \\
\text { University, } \\
\text { Fukushima }\end{array}$ & Author & $\begin{array}{l}\text { Collected clinical data } \\
\text { and blood samples of } \\
\text { study patients }\end{array}$ \\
\hline $\begin{array}{l}\text { Hiroki } \\
\text { Sakamoto, } \\
\text { MD }\end{array}$ & $\begin{array}{l}\text { Kansai Medical } \\
\text { University, Hirakata }\end{array}$ & Author & $\begin{array}{l}\text { Collected clinical } \\
\text { data and blood } \\
\text { samples of study } \\
\text { patients }\end{array}$ \\
\hline $\begin{array}{l}\text { Satoshi } \\
\text { Kaneko, } \\
\text { MD, PhD }\end{array}$ & $\begin{array}{l}\text { Kansai Medical } \\
\text { University, Hirakata }\end{array}$ & Author & $\begin{array}{l}\text { Collected clinical } \\
\text { data and blood } \\
\text { samples of study } \\
\text { patients }\end{array}$ \\
\hline $\begin{array}{l}\text { Yusuke } \\
\text { Nakazawa, } \\
\text { MD }\end{array}$ & $\begin{array}{l}\text { Kyushu University, } \\
\text { Fukuoka }\end{array}$ & Author & $\begin{array}{l}\text { Collected clinical } \\
\text { data and blood } \\
\text { samples of study } \\
\text { patients }\end{array}$ \\
\hline $\begin{array}{l}\text { Ryo } \\
\text { Yamasaki, } \\
\text { MD, PhD }\end{array}$ & $\begin{array}{l}\text { Kyushu University, } \\
\text { Fukuoka }\end{array}$ & Author & $\begin{array}{l}\text { Collected clinical data } \\
\text { and blood samples of } \\
\text { study patients }\end{array}$ \\
\hline $\begin{array}{l}\text { Shoko } \\
\text { Sadashima, } \\
\text { MD }\end{array}$ & $\begin{array}{l}\text { Kyushu University, } \\
\text { Fukuoka }\end{array}$ & Author & $\begin{array}{l}\text { Collected clinical data } \\
\text { and blood samples of } \\
\text { study patients }\end{array}$ \\
\hline
\end{tabular}




\begin{tabular}{llll} 
Appendix & (continued) & & \\
\hline Name & Location & Role & Contribution \\
\hline $\begin{array}{l}\text { Toshiaki } \\
\text { Sakai, MD }\end{array}$ & $\begin{array}{l}\text { Nagano Matsushiro } \\
\text { General Hospital, } \\
\text { Nagano }\end{array}$ & Author & $\begin{array}{l}\text { Collected clinical data } \\
\text { and blood samples of } \\
\text { study patients }\end{array}$ \\
\hline $\begin{array}{l}\text { Hiroaki } \\
\text { Arai, MD }\end{array}$ & $\begin{array}{l}\text { Nagano Matsushiro } \\
\text { General Hospital, }\end{array}$ & Author & $\begin{array}{l}\text { Collected clinical data } \\
\text { and blood samples of } \\
\text { study patients }\end{array}$ \\
\hline $\begin{array}{l}\text { Akira Sano, } \\
\text { MD, PhD }\end{array}$ & $\begin{array}{l}\text { Kagoshima } \\
\text { University Graduate } \\
\text { School of Medical } \\
\text { and Dental Sciences, } \\
\text { Kagoshima }\end{array}$ & Author & $\begin{array}{l}\text { Advised on data } \\
\text { analysis, prepared } \\
\text { the manuscript, and } \\
\text { served as a scientific } \\
\text { advisor }\end{array}$ \\
& & & \\
\hline
\end{tabular}

\section{References}

1. Ueno S, Maruki Y, Nakamura M, et al. The gene encoding a newly discovered protein, chorein, is mutated in chorea-acanthocytosis. Nat Genet 2001;28:121-122.

2. Rampoldi L, Dobson-Stone C, Rubio JP, et al. A conserved sorting-associated protein is mutant in chorea-acanthocytosis. Nat Genet 2001;28:119-120.

3. Tomiyasu A, Nakamura M, Ichiba M, et al. Novel pathogenic mutations and copy number variations in the VPS13A Gene in patients with chorea-acanthocytosis. Am J Med Genet B 2011;156:620-631.

4. Dobson-Stone C, Velayos-Baeza A, Filippone LA, et al. Chorein detection for the diagnosis of Chorea-acanthocytosis. Ann Neurol 2004;56:299-302.

5. Ho M, Chelly J, Carter N, Danek A, Crocker P, Monaco AP. Isolation of the gene for McLeod syndrome that encodes a novel membrane transport protein. Cell 1994;77:869-880.

6. Jung HH, Danek A, Walker RH. Neuroacanthocytosis syndromes. Orphanet J Rare Dis $2011 ; 6: 68$.

7. Narumi S, Natori T, Miyazawa H, et al. Case of McLeod syndrome with a novel genetic mutation. Neurol Clin Neurosci 2016;4:115-117.

8. Shiokawa N, Nakamura M, Sameshima M, et al. Chorein, the protein responsible for chorea-acanthocytosis, interacts with $\beta$-adducin and $\beta$-actin. Biochem Biophys Res Commun 2013;441:96-101.

9. Ichiba M, Nakamura M, Kusumoto A, et al. Clinical and molecular genetic assessment of a chorea-acanthocytosis pedigree. J Neurol Sci 2007;263:124-132.

10. De Franceschi L, Scardoni G, Tomelleri C, et al. Computational identification of phospho-tyrosine sub-networks related to acanthocyte generation in neuroacanthocytosis. PLoS One 2012;7:e31015. 


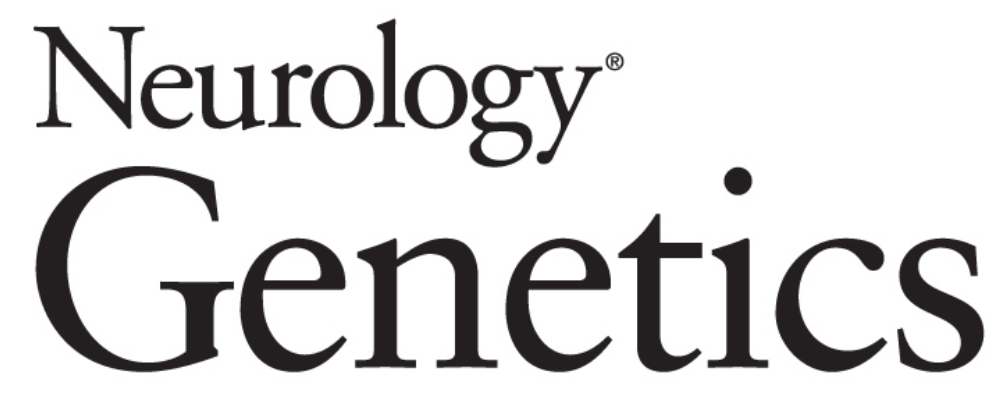

\section{Novel pathogenic $X K$ mutations in McLeod syndrome and interaction between XK protein and chorein \\ Yuka Urata, Masayuki Nakamura, Natsuki Sasaki, et al. Neurol Genet 2019;5; \\ DOI 10.1212/NXG.0000000000000328}

\section{This information is current as of April 22, 2019}

\section{Updated Information \&} Services

References

Citations

Permissions \& Licensing

Reprints including high resolution figures, can be found at: http://ng.neurology.org/content/5/3/e328.full.html

This article cites 10 articles, 0 of which you can access for free at: http://ng.neurology.org/content/5/3/e328.full.html\#\#ref-list-1

This article has been cited by 3 HighWire-hosted articles: http://ng.neurology.org/content/5/3/e328.full.html\#\#otherarticles

Information about reproducing this article in parts (figures,tables) or in its entirety can be found online at:

http://ng.neurology.org/misc/about.xhtml\#permissions

Information about ordering reprints can be found online: http://ng.neurology.org/misc/addir.xhtml\#reprintsus

Neurol Genet is an official journal of the American Academy of Neurology. Published since April 2015, it is an open-access, online-only, continuous publication journal. Copyright ( $)$ The Author(s). Published by Wolters Kluwer Health, Inc. on behalf of the 2019 American Academy of Neurology.. All rights reserved. Online ISSN: 2376-7839.

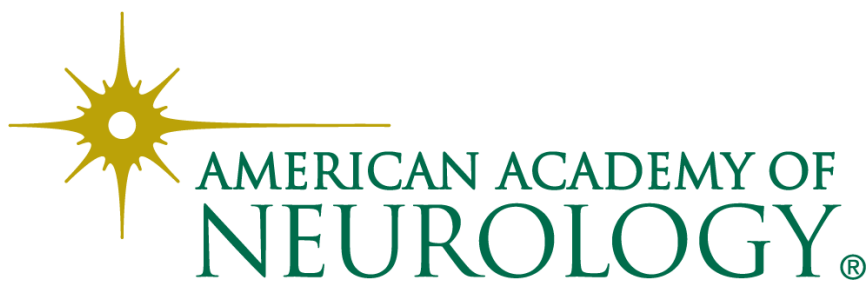

